\title{
SMALL MAMMALS OF CHAPADA DOS VEADEIROS NATIONAL PARK (CERRADO OF CENTRAL BRAZIL): ECOLOGIC, KARYOLOGIC, AND TAXONOMIC CONSIDERATIONS
}

\author{
BONVICINO, C. R.. ${ }^{1,2}$ LEMOS, B..$^{1,3}$ and WEKSLER, M. ${ }^{4}$ \\ ${ }^{1}$ Genetics Division, Instituto Nacional de Câncer, Rua André Cavalcanti, 37, $4^{\text {th }}$ floor, CEP 20230-130, \\ Rio de Janeiro, Brazil \\ ${ }^{2}$ Department of Tropical Medicine, IOC-FIOCRUZ, Av. Brasil, 4365, Manguinhos, CEP 21045-900, Rio de Janeiro \\ ${ }^{3}$ Laboratório de Vertebrados, Universidade Federal do Rio de Janeiro \\ ${ }^{4}$ Department of Mammalogy, American Museum of Natural History, NY, USA \\ Correspondence to: Cibele R. Bonvicino, Genetics Division, Instituto Nacional de Câncer, Rua André Cavalcanti, \\ 37, $4^{\circ}$ andar, CEP 20231-050, Rio de Janeiro, RJ, Brazil e-mail: cibelerb@ inca.gov.br \\ Received June 11, 2003 - Accepted March 18, 2004 - Distributed August 31, 2005
}

(With 2 figures)

\begin{abstract}
This work is based on a survey of small mammals carried out in the Chapada dos Veadeiros National Park, a natural reserve located in the mountains of the Planalto Central Goiano in the Cerrado of Central Brazil. The 227 specimens collected represented six marsupial and 13 rodent species. Taxonomic, karyologic, and ecologic considerations are present and discussed in the present work. Our data reflected the faunal heterogeneity with respect to both elevation and vegetation because only eight of the 19 species were collected at both high and low elevations. The composition of the small mammal fauna of the park is influenced by predominance of forest formations at low elevations and cerrado with rupestrian areas at high elevations. Presence of endemic species and one undescribed demonstrated that the cerrado has an endemic fauna and a little known diversity of small mammals.
\end{abstract}

Key words: Brazil, cerrado, karyotype, marsupials, small rodents, taxonomy.

\section{RESUMO}

Pequenos mamíferos do Parque Nacional da Chapada dos Veadeiros (Cerrado do Brasil Central): considerações ecológicas, cariológicas e taxonômicas

Este trabalho é baseado em um levantamento sobre pequenos mamíferos realizado no Parque Nacional da Chapada dos Veadeiros, localizado nas montanhas do Planalto Central Goiano, no Cerrado do Brasil Central. Foram coletadas 227 espécimes, representando 6 espécies de marsupiais e 13 de roedores. Considerações taxonômicas, cariológicas e ecológicas são apresentadas e discutidas. Nossos dados refletem a heterogeneidade da fauna em relação à altitude e à vegetação do Cerrado, sendo apenas 8 das 19 espécies coletadas comuns às altitudes elevadas e baixas. A composição da fauna de pequenos mamíferos do parque está influenciada pela predominância de formações florestais nas altitudes baixas e de cerrado rupestre nas altitudes elevadas. A presença de espécies endêmicas e uma ainda não descrita demonstram que o Cerrado apresenta uma fauna endêmica associada, sendo pouco entendida a diversidade de seus pequenos mamíferos.

Palavras-chave: Brasil, Cerrado, cariótipo, marsupiais, pequenos mamíferos, taxonomia. 


\section{INTRODUCTION}

The cerrado is the most extensive openvegetation biome of South America and one of the largest savanna-forest complexes in the world. With a core area spanning over $1.8-2$ million $\mathrm{km}^{2}$ on the Brazilian plateau, the cerrado is located in the middle portion of an open-vegetation belt between the Argentinean-Paraguayan Chaco and the caatinga of northeastern Brazil.

This open-vegetation belt separates two major mesophytic biomes, the Atlantic rainforest and the Amazonian rainforest. Enclaves of typical cerrado physiognomy occur within other biomes. At its core area, the cerrado is characterized by an often well-delimited mosaic of vegetation types with abundant ecological islands and corridors, forming a savanna-forest complex (Eiten, 1972, 1983).

The orders Rodentia and Didelphimorphia are the major components of the cerrado mammalian fauna (Redford \& Fonseca, 1986). Given the degree of physiognomical complexity of the biome, it is natural that several studies have been devoted to the description of the small mammal composition associated with habitat heterogeneity. These studies primarily center on differences between areas of open vegetation and gallery forest (Henriques \& Alho, 1981; Fonseca \& Redford, 1984; Mares et al., 1986, 1989; Marinho Filho et al., 1994; Bonvicino et al., 1996a).

But few reports have focused on the historical component in the cerrado's faunal diversity (Redford $\&$ Fonseca, 1986) or the variation of fauna composition in relation to the different cerrado floristic sub-compartments. Furthermore, taxonomic studies of the cerrado's small mammal fauna are generally restricted in number of taxa (e.g., Voss \& Myers, 1991; Bonvicino \& Weksler, 1998; Bonvicino et al., 1998, 2002). The limited knowledge of the taxonomy of the cerrado's small mammals (Patterson, 2000) is reflected by several recent studies either describing new species (Moojen et al., 1997; Bonvicino \& Weksler, 1998; Langguth \& Bonvicino, 2002; Bonvicino, 2003), or stressing taxonomic problems (Oliveira, 1998; Bonvicino et al., 1999). As a result, species misidentifications are common, including the usage of nomima nuda (e.g. Plectomys paludicola, Alho et al., 1986), or the use of names corresponding to species groups for selected taxa (e.g. O. subflavus, Alho et al., 1986).
In this paper we present a taxonomic account of the species collected at the Chapada dos Veadeiros National Park in the cerrado of central Brazil. We report on part of the diversity of small mammals of the cerrado and, due to the lack of previous taxonomic studies, we discuss problems of species identification. Finally, we consider some simple ecological and geographical patterns.

\section{MATERIALS AND METHODS}

\section{Study site and sampling design}

Small mammals were sampled in three areas in the Chapada dos Veadeiros National Park (Fig. 1) representing most of its vegetation and elevation diversity. We followed Eiten $(1972,1983)$ for identification and description of vegetation types. The park is located in a mountainous region, the Planalto Central Goiano (Radam-Brasil, 1983) that include the highest peak of Goiás State (Pouso Alto, with 1,784 m). Area 1 was sampled in August 1996 and areas 2 and 3 in November 1996. Sherman and Tomahawk traps were spaced 15-20 m on ground line transects.

Area 1 (A1 - 14 ${ }^{\circ} 04^{\prime} \mathrm{S}, 47^{\circ} 45^{\prime} \mathrm{W}$, near Morro do Chapéu, $65 \mathrm{~km} \mathrm{SSW}$ of Cavalcante), whose collecting elevation ranged from 550 to $740 \mathrm{~m}$, is in the lowest part of the park. A1 is a forest formation domain with extensive gallery forests bordered by cerradão (an evergreen vegetation with few deciduous trees but floristically different from semideciduous forest). A total of 991 trap-nights were spent in gallery forest (GF), cerradão (CD), cerrado rupestre (CR: thinly wooded savanna vegetation with rock outcrops), cerrado sensu stricto (CE: wooded savanna), and campo úmido (CU: a mesic grassland). Area 2 (A2 - $1^{\circ} 01^{\prime} \mathrm{S}, 47^{\circ} 31^{\prime} \mathrm{W}$, near Pouso Alto, $14 \mathrm{~km}$ NNW of Alto Paraíso), in the highest part of the park between 1,300 and 1,500 m of altitude, is a domain of open vegetation formations with extensive areas of cerrado rupestre and natural grass fields. A total of 1,208 trap nights were spent in GF, CE, CR, and CU. Area 3 (A3 - 14 ${ }^{\circ} 07^{\prime} \mathrm{S}, 47^{\circ} 41^{\prime} \mathrm{W}$, near Morro da Baleia, $20 \mathrm{~km} \mathrm{~W}$ of Alto Paraíso), which included collecting altitudes ranging from 1,000 to $1,200 \mathrm{~m}$, is a domain of open vegetation formations with extensive areas of vereda (VE: wet headwater prairies with palms) and natural fields. A total of 466 trap-nights were placed in GF, campo cerrado (CC: scarcely wooded savanna), and VE. 
Chromosome preparations of rodent specimens were obtained from bone marrow cultures in RPMI $1640,20 \%$ fetal calf serum, ethidium bromide $(5 \mu \mathrm{g} /$ $\mathrm{ml})$, and colchicine $\left(10^{-6} \mathrm{M}\right)$ for $2 \mathrm{~h}$. The abbreviation FN refers to autosome fundamental number. Skins and skulls are deposited in the mammal collection of the Museu Nacional (MN, Universidade Federal do Rio de Janeiro, Brazil). Collected specimens are listed in the species account; the abbreviation CRB preceding field number digits stands for C. R. Bonvicino. External measurements were obtained from collected adult specimens. Measurements (in millimeters) taken from adult specimens were head/body length (HB), tail length (T), feet length, including claws $(\mathrm{F})$, internal length of the ear (E), and weight, in grams (W).

\section{RESULTS}

Six marsupial and 13 rodent species were collected. The marsupials Micoureus demerarae, Didelphis albiventris, and Gracilinanus agilis were trapped only in the lower part of the park (A1), Thylamys velutinus and Monodelphis umbristriata only in the highest part of the park (A2), and Monodelphis domestica in both. The rodents Oryzomys lamia, Oligoryzomys sp. 1, and Proechimys roberti were collected only in A1; Oligoryzomys sp. 2, Pseudoryzomys simplex, and Galea cf. flavidens only in the high part of the park (A2 - A3); and Thrichomys sp., Calomys expulsus, Oxymycterus delator, Necromys lasiurus, Oryzomys megacephalus, Oryzomys scotti, and Nectomys rattus in both areas.

\section{SPECIES ACCOUNT}

\section{Didelphimorphia - Didelphidae Didelphis albiventris Lund, 1840}

Taxonomy: populations of the white-eared opossum occurring in cerrado have been synonymized as $D$. albiventris (D. albiventris albiventris sensu Cerqueira, 1985).

Distribution: Paraguay; Uruguay; Northern Argentina; Bolivia; and northeastern (NE), central (C), and southern (S) Brazil, in cerrado, caatinga, the Pantanal, chaco, and humid pampa (Cerqueira, 1985; Gardner, 1993); finally, disjunct distributions in Peru, Ecuador, Colombia, southern Venezuela,
French Guyana, Suriname, and northern (N) Brazil may represent other taxa (see above).

Ecological notes and reproduction: a single pregnant female (six embryos) collected in cerrado sensu stricto at the edge of gallery forest (area A1, August).

\section{Specimen collected: MN46514 Micoureus demerarae (Thomas, 1905)}

Taxonomy: $M$. demerarae, as recognized by Gardner (1993), includes several forms previously accepted as valid species or subspecies of the Marmosa cinerea group (Tate, 1933). M. demerarae is probably a composite, and Patton et al. (2000) regarded the Atlantic Forest populations as a distinct taxon (M. limae); however, Gardner (1993) treated $M$. limae and $M$. paraguayanus as synonymous with $M$. demerarae. The assignment of the Micoureus population in Chapada dos Veadeiros National Park (PNCV) to M. demerarae is provisional, as a more comprehensive analysis of the status of this genus is needed.

Distribution: Colombia, Peru, Bolivia, Venezuela, French Guyana, Guyana, Surinam, and $\mathrm{N}$ and $\mathrm{C}$ Brazil, in cerrado, caatinga, Amazon Forest, and the Pantanal (Patton et al., 2000).

Ecological notes and reproduction: six individuals collected, three in gallery forest, two in cerrado sensu stricto and 1 in cerrado rupestre (area A1). Females were not pregnant or carrying pouched young (August).

Measurements: $\mathrm{HB}=134-174, \mathrm{~T}=193-252$, $\mathrm{F}=25-28, \mathrm{E}=25-30, \mathrm{~W}=65-110$. 885 .

Specimens collected: MN46880-881, 46883-

\section{Gracilinanus agilis (Burmeister, 1854)}

Taxonomy: G. agilis, as defined by Gardner \& Creighton (1989), Hershkovitz (1992), and Gardner (1993), includes as synonymous all forms regarded as subspecies by Tate (1933); however, this arrangement lacks character corroboration (Hershkovitz, 1992). All forms described for the cerrado of central Brazil have been synonymized as G. agilis (G. agilis agilis of Tate, 1933; see also Cabrera, 1957).

Distribution: Uruguay, Paraguay, Argentina, Bolivia, and NE and C Brazil, in cerrado, caatinga, chaco, and the Pantanal (Hershkovitz, 1992); 
disjunct distribution in Peru and Colombia may represent another taxon (see above).

Ecological notes and reproduction: 19 individuals collected, 11 in cerrado sensu stricto, 7 in cerradão, and 1 in campo úmido (area A1). Females were not pregnant or carrying pouched young (August).

Measurements: $\mathrm{HB}=92-129, \mathrm{~T}=126-164$, $\mathrm{F}=12-22, \mathrm{E}=20-24, \mathrm{~W}=20-45$.

Specimens collected: MN46538-550, 46552, 46568, 46576.

\section{Monodelphis domestica (Wagner, 1842)}

Taxonomy: M. domestica is the only name used for the majority of gray short-tailed opossum populations, including all those in the cerrado. An isolate population in Marajó, an island in the delta of the Amazon river, Amazon State, is taxonomically controversial, being regarded as a distinct species by some authors (M. maraxina; see Pine, 1979; Gardner, 1993).

Distribution: Bolivia, Paraguay, and NE and C Brazil, in the cerrado, caatinga, and chaco (Gardner, 1993).

Ecological notes and reproduction: 22 individuals collected, 2 in cerradão, 8 in cerrado sensu stricto, 5 in gallery forest, 5 in cerrado rupestre, 2 in campo úmido, and 1 in campo cerrado (areas A1 and A3). Females were not pregnant or carrying pouched young (August and November).

Measurements: HB $=105-200, \mathrm{~T}=62-89$, $\mathrm{F}=15-27, \mathrm{E}=17-24, \mathrm{~W}=34-75$. 586.

Specimens collected: MN46572-580, 46582-

Monodelphis umbristriata Miranda-Ribeiro, 1936

Taxonomy: the specific status of $M$. umbristriata was recently altered following comparisons among $M$. umbristriata, $M$. rubida, and $M$. americana that showed differences in pelage and cranial characters (Lemos et al., 2000).

Distribution: known only in the cerrado of central Brazil (Lemos et al., 2000).

Ecological notes: A single individual collected in gallery forest (area A2).

Measurements: $\mathrm{HB}=155, \mathrm{~T}=60, \mathrm{~F}=21, \mathrm{E}=$ $18, \mathrm{~W}=90$.

Specimen collected: MN46570.

\section{Thylamys velutinus (Wagner, 1842)}

Taxonomy: $T$. velutinus is the only species of Thylamys occurring in the cerrado of central Brazil (Palma, 1995). Although Gardner (1993) synonymized T. karimii with T. pusillus, Palma (1995) presented morphological arguments for the inclusion of T. karimii under T. velutinus, and restricted the distribution of T. pusillus to Paraguay, Bolivia, and Argentina. The characters of the single captured specimen match those given by Tate (1933) and Palma (1995).

Distribution: NE, SE, and C Brazil, in the cerrado, caatinga and Atlantic Forest (Palma, 1995).

Ecological notes: A single individual collected in campo úmido, at the edge of gallery forest (area A2).

Measurements: $\mathrm{HB}=111, \mathrm{~T}=76$ (measurements taken from the voucher specimens).

Specimen collected: CRB1075 (skull and skeleton only).

\section{RODENTIA}

\section{Caviidae \\ Galea cf. flavidens (Brandt, 1835)}

Taxonomy: G. flavidens is considered a valid species (e.g., Cabrera, 1961; Woods, 1993), with clear morphological differences from G. spixii; however, its relationship with $G$. bilobidens is controversial (Paula-Couto, 1950), as has been including G. bilobidens within the genus Galea. For this reason, based on morphological characters we tentatively refer to our specimens as Galea cf. flavidens.

Distribution: Brazil (Woods, 1993), restricted to the cerrado by Redford \& Fonseca (1986).

Ecological notes and reproduction: three individuals collected in cerrado rupestre (area A2). One pregnant female (one embryo) was collected in November.

Measurements: $\mathrm{HB}=205-231, \mathrm{~F}=43-47, \mathrm{E}=$ 24-25, $\mathrm{W}=150-330$.

Specimens collected: CRB1078, 1089, 1108.

\section{Echimyidae \\ Thrichomys sp. (Lund, 1839)}

Taxonomy and karyotype: Thrichomys apereoides was traditionally considered the only 
valid species of the genus (Woods, 1993). Recently, this genus was shown to be polytypic and proper names have been proposed: Thrichomys inermis (populations with $2 \mathrm{n}=26, \mathrm{FN}=48$ ), Thrichomys pachyurus (populations with $2 \mathrm{n}=34$ ), Thrichomys apereoides apereoides (populations with $2 \mathrm{n}=28, \mathrm{FN}=50$ ), Thrichomys apereoides laurentius (populations with $2 \mathrm{n}=30, \mathrm{FN}=54$ ), and Thrichomys sp. (populations with $2 \mathrm{n}=30, \mathrm{FN}=56$; Bonvicino et al., 2002). Karyologic analyses of collected specimens showed $2 \mathrm{n}=30, \mathrm{FN}=56$ (Fig. 2A).

Distribution: NE and C Brazil, in cerrado of Tocantins, Goiás, and Minas Gerais States.

Ecological notes and reproduction: 25 individuals collected, 16 in cerrado rupestre, 5 in cerrado sensu stricto, 2 in cerradão, 1 in campo cerrado, and 1 in campo úmido (areas A1, A2 and A3). One pregnant female (one embryo) was collected in November.

Measurements: $\mathrm{HB}=187-214, \mathrm{~T}=138, \mathrm{~F}=$ 39-46, $\mathrm{E}=20-25, \mathrm{~W}=170-335$.

Specimens collected: MN50177.

\section{Proechimys roberti Thomas (1901)}

Taxonomy and karyotype: $P$. roberti has been considered a junior synonym of $P$. longicaudatus (Woods, 1993), or as a valid species (Patton, 1987; Pessoa et al., 1990) or, further, as subspecies of either P. longicaudatus (Moojen, 1948; Cabrera, 1961) or $P$. cayennensis (= P. guyannensis) (Ellerman, 1940). Karyologic, morphologic, and molecular analysis showed that $P$. roberti is a valid species of the guyannensis species group (sensu Patton, 1987), with $P$. oris a junior synonym (Weksler $e t$ al., 2001). Karyologic analyses showed $2 \mathrm{n}=30$, $\mathrm{FN}=54-55$ (Fig. 2B). Variation in FN was due to a single pericentric inversion in one member of a small autosome pair.

Distribution: $\mathrm{S}$ of the Amazon river, $\mathrm{C}$ and $\mathrm{N}$ Brazil (Federal District, Minas Gerais, Goiás, Tocantins, Maranhão and Pará), in cerrado and the Amazon Forest (Weksler et al., 2001).

Ecological notes and reproduction: 32 individuals collected, 27 in gallery forest, 3 in cerradão, and 2 in cerrado sensu stricto on the edge of gallery forest (area A1). Five pregnant females were collected in August (2-3 embryos each).

Measurements: $\mathrm{HB}=178-285, \mathrm{~T}=115-181$, $\mathrm{F}=42-55, \mathrm{E}=26, \mathrm{~W}=120-410$.

Specimens collected: MN50193-223, 50227.

\section{Muridae \\ Nectomys rattus (Pelzen, 1883)}

Taxonomy and karyotype: $N$. rattus is considered a junior synonym of $N$. squamipes (Musser \& Carleton, 1993) but Bonvicino et al. (1996b) showed that the populations with $2 n=52$ and $2 \mathrm{n}=56$, previously considered two karyologic variants within $N$. squamipes (Maia et al., 1984), were different species that produced sterile hybrids due to abnormal spermatogenesis. Nectomys rattus is the most appropriate name for Nectomys with $2 \mathrm{n}=52$ (Bonvicino, 1994). Karyologic analysis showed $2 \mathrm{n}=52, \mathrm{FN}=52$ (Fig. 2C).

Distribution: E Magdalena river basin in Colombia, throughout Venezuela (high and median Orinoco river basin), Peru (Ucayali river basin), Paraguay (Paraguay river basin), and Brazil (in the Paraguay and Amazons river basins; Bonvicino, 1994).

Ecological notes and reproduction: 11 individuals collected in gallery forest and vereda, always near water streams (areas A1, A2, and A3). Females were not pregnant (August and November).

Measurements: $\mathrm{HB}=168-245, \mathrm{~T}=182-244$, $\mathrm{F}=49-56, \mathrm{E}=21-26, \mathrm{~W}=130-340$.

Specimens collected: MN46873, 46889-892, 46895, 50291 .

\section{Pseudoryzomys simplex (Winge, 1887)}

Taxonomy and karyotype: Pseudoryzomys is considered to be a monospecific genus with all previously described species and subspecies regarded as synonyms of $P$. simplex (Voss \& Myers, 1991; Musser \& Carleton, 1993). Karyologic analysis showed $2 \mathrm{n}=56, \mathrm{FN}=54$.

Distribution: N Argentina, W Paraguay, E Bolivia, and $\mathrm{E}$ and $\mathrm{C}$ Brazil, in cerrado, caatinga, chaco, and Pantanal (Voss \& Myers, 1991).

Ecological notes and reproduction: 2 individuals collected in vereda (area A3). Females were not pregnant (November).

Measurements: $\mathrm{HB}=115-124, \mathrm{~T}=115, \mathrm{~F}=$ $29, \mathrm{E}=18, \mathrm{~W}=45-55$.

Specimens collected: CRB1115, 1127.

\section{Oryzomys megacephalus (Fischer, 1814)}

Taxonomy and karyotype: O. megacephalus has priority over the much-used name $O$. capito (Langguth, 1966; Musser et al., 1998). Several species of Oryzomys were formerly included as 
synonyms or subspecies under $O$. capito (e.g. Cabrera, 1961), but a series of reports found a large karyologic and morphologic variability among included forms (Gardner \& Patton, 1976; Musser et al., 1998). The revision of Musser et al. (1998) partially rectified this situation, with a preliminary specific delimitation of $O$. megacephalus that included all cerrado populations. Karyologic analysis showed $2 \mathrm{n}=54, \mathrm{FN}=62$ (Fig. 2D). This karyotype had previously been attributed to $O$. capito laticeps (Svartman \& Almeida, 1992) and O. megacephalus (Musser et al., 1998).

Distribution: Paraguay, Peru, southern Venezuela, Guyana, French Guyana, Suriname, and central and northern Brazil in the cerrado and Amazon Forest (Musser \& Carleton, 1993).

Ecological notes and reproduction: 11 individuals collected, 9 in gallery forest, 1 in cerradão, and 1 in cerrado sensu stricto (areas A1 and A2). One pregnant female was collected in August (3 embryos) and one in November (4 embryos).

Measurements: $\mathrm{HB}=114-158, \mathrm{~T}=107-162$, $\mathrm{F}=27-35, \mathrm{E}=17-25, \mathrm{~W}=30-100$.

Specimens collected: MN46859, 46861, 46863-867, 46870-871, 50290.

\section{Oryzomys lamia Thomas, 1901}

Taxonomy and karyotype: O. lamia was considered a junior synonym of Oryzomys russatus (= O. intermedius) by Musser et al. (1998), but its karyotype and morphology clearly differed from other Oryzomys species (Bonvicino et al., 1998). Karyologic analysis showed $2 \mathrm{n}=58, \mathrm{FN}=84$ (Fig. 2E).

Distribution: endemic to the cerrado of $\mathrm{C}$ Brazil (Minas Gerais and Goiás States).

Ecological notes and reproduction: seven individuals collected, three in gallery forest, two in cerradão, one in cerrado sensu stricto on the edge of gallery forest, and one in campo úmido on the edge of gallery forest (A1). Females were not pregnant (August).

Measurements: $\mathrm{HB}=141-161, \mathrm{~T}=131-160$, $\mathrm{F}=34-36, \mathrm{E}=20-25, \mathrm{~W}=40-85$.

Specimens collected: MN46826, CRB926, 964, 968, 969, 983, 1024.
Oryzomys scotti Langguth and Bonvicino, 2002

Taxonomy and karyotype: this taxon is the most common species of the Oryzomys subflavus species group. It differs from the other taxa of the Oryzomys subflavus species group in its smaller body size, proportionally larger ear, lighter pelage coloration, and the presence of an alisphenoid strut. It differs from other cerrado Oryzomys species (not belonging to $O$. subflavus group) by its long incisive foramen, and absence of well-defined limits between the ventral and dorsal coloration. Karyologic analysis showed $2 \mathrm{n}=58, \mathrm{FN}=72$ (Fig. 2F).

Distribution: endemic in Brazilian cerrado (Federal District and Minas Gerais, Bahia, Southern Goiás, Mato Grosso do Sul, and Rondônia States).

Ecological notes and reproduction: 14 individuals collected, 7 in cerrado sensu stricto, 3 in cerrado rupestre, 3 in campo úmido, and 1 in campo cerrado (areas A1 and A2). Two pregnant females were collected in August ( 3 and 4 embryos each).

Measurements: HB = 137-168, T = 139-169, $\mathrm{F}=30-35, \mathrm{E}=19-25, \mathrm{~W}=50-100$.

Specimens collected: MN61674-680, 61682, 61684-688.

Oligoryzomys moojeni Weksler \& Bonvicino, 2005

Taxonomy and karyotype: this is a recently described species belonging to the small-sized and yellow-bellied Oligoryzomys species group (composed of $O$. fornesi, $O$. flavescens, and $O$. microtis; Bonvicino \& Weksler, 1998), and having a different chromosome complement from all other described Oligoryzomys species. Karyologic analysis showed 2n = 70, FN = 74 (Fig. 2G).

Distribution: endemic in the cerrado of $\mathrm{C}$ Brazil (Minas Gerais, Goiás, and Tocantins states).

Ecological notes and reproduction: 12 individuals collected, 6 in cerrado sensu stricto, 2 in campo úmido on the edge of cerrado sensu stricto, 3 in open gallery forest with bamboo trees, and 1 in cerradão on the edge of cerrado sensu stricto (area A1). Two pregnant females were collected in August (3 embryos each).

Measurements: $\mathrm{HB}=77-97, \mathrm{~T}=93-132$, $\mathrm{F}=21-25, \mathrm{E}=12-16, \mathrm{~W}=10-25$. 
Specimens collected: MN50287, 50307-315, 50377-378.

\section{Oligoryzomys rupestris Weksler \& Bonvicino, 2005}

Taxonomy and karyotype: this is another undescribed Oligoryzomys species with a different chromosome complement from all other members thus far described of that species, and presenting one of the lowest diploid numbers in this genus. Karyologic analysis showed $2 \mathrm{n}=46, \mathrm{FN}=52$ (Fig. $2 \mathrm{H}$ ). A similar karyotype was previously attributed to Oligoryzomys sp.1 (Silva \& Yonenaga-Yassuda, 1997).

Distribution: endemic to high altitude areas in the cerrado of C Brazil (Minas Gerais, Bahia, and Goiás states).

Ecological notes and reproduction: 9 individuals collected in cerrado rupestre or on the edge of this vegetation (area A2). Females were not pregnant (November).

Measurements: $\mathrm{HB}=65-99, \mathrm{~T}=105-138, \mathrm{~F}=$ 20-25, E = 12-17, $\mathrm{W}=10-20$.

Specimens collected: MN50286, 50322-328.

\section{Necromys lasiurus (Lund, 1841)}

Taxonomy and karyotype: several subspecies have been described for Necromys lasiurus (= Bolomys lasiurus) but karyologic and morphometric analysis revealed a homogeneous species throughout much of its distribution (Macêdo \& Mares, 1987; Svartman \& Almeida, 1993). The taxonomic status of E Amazon populations is still controversial due to their marked morphometric and developmental differences from cerrado populations (Macêdo \& Mares, 1987), of which all forms have been synonymized under B. lasiurus. Karyologic analyses showed $2 \mathrm{n}=34, \mathrm{FN}=34$ (Fig. 2I).

Distribution: E Bolivia, Paraguay, N Argentina, and Brazil S of the Amazon river in cerrado, caatinga, chaco, the Pantanal and the Atlantic Forest (Alho, 1982; Macêdo \& Mares, 1987).

Ecological notes and reproduction: 21 individuals collected, 4 in vereda, 3 in cerrado rupestre on the edge of campo úmido, 2 in cerrado sensu stricto, and 12 in campo úmido (areas A1, A2 and A3). Females were not pregnant (August and November). Measurements: $\mathrm{HB}=83-136, \mathrm{~T}=66-91, \mathrm{~F}=$ 20-26, $\mathrm{E}=13-17, \mathrm{~W}=40-80$.

Specimens collected: MN46811, 46813, 46818, 46820-824, 46828, 46830, 46832.

\section{Oxymycterus delator Thomas, 1903}

Taxonomy and karyotype: Oxymycterus specimens of the cerrado of $\mathrm{C}$ Brazil have been traditionally identified as $O$. roberti (Hershkovitz, 1994). However, a taxonomic revision of the genus (Oliveira, 1998) showed that cerrado populations are included in $O$. delator, a species that was formerly restricted to Paraguay, and that $O$. roberti has restricted distribution in S Goiás and Minas Gerais. Karyologic analyses showed $2 \mathrm{n}=54, \mathrm{FN}=$ 62 (Fig. 2J). All species of this genus (sensu Hershkovitz, 1998) share the same karyotype.

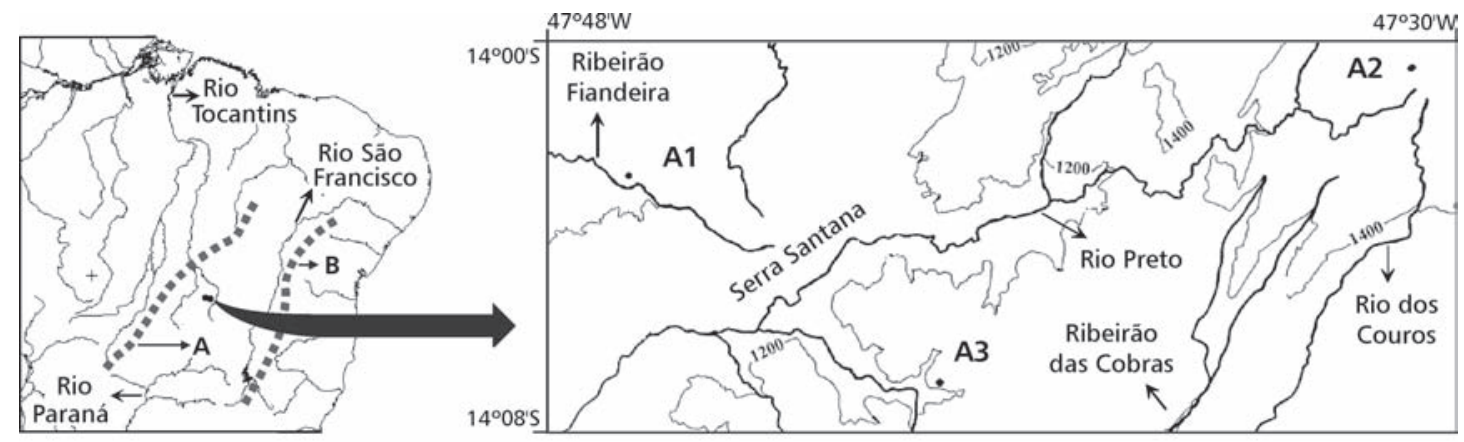

Fig. 1 - n Chapada dos Veadeiros National Park located in the Planalto Central Goiano (A), separated by the rio São Francisco from the Planalto do Espinhaço mountains (B). Collecting sites in Chapada dos Veadeiros National Park. A1: near Morro do Chapéu, 65 km SSW of Cavalcante; A2: near Pouso Alto, 14 km NNW of Alto Paraíso; A3: near Morro da Baleia, 20 km W of Alto Paraíso. 


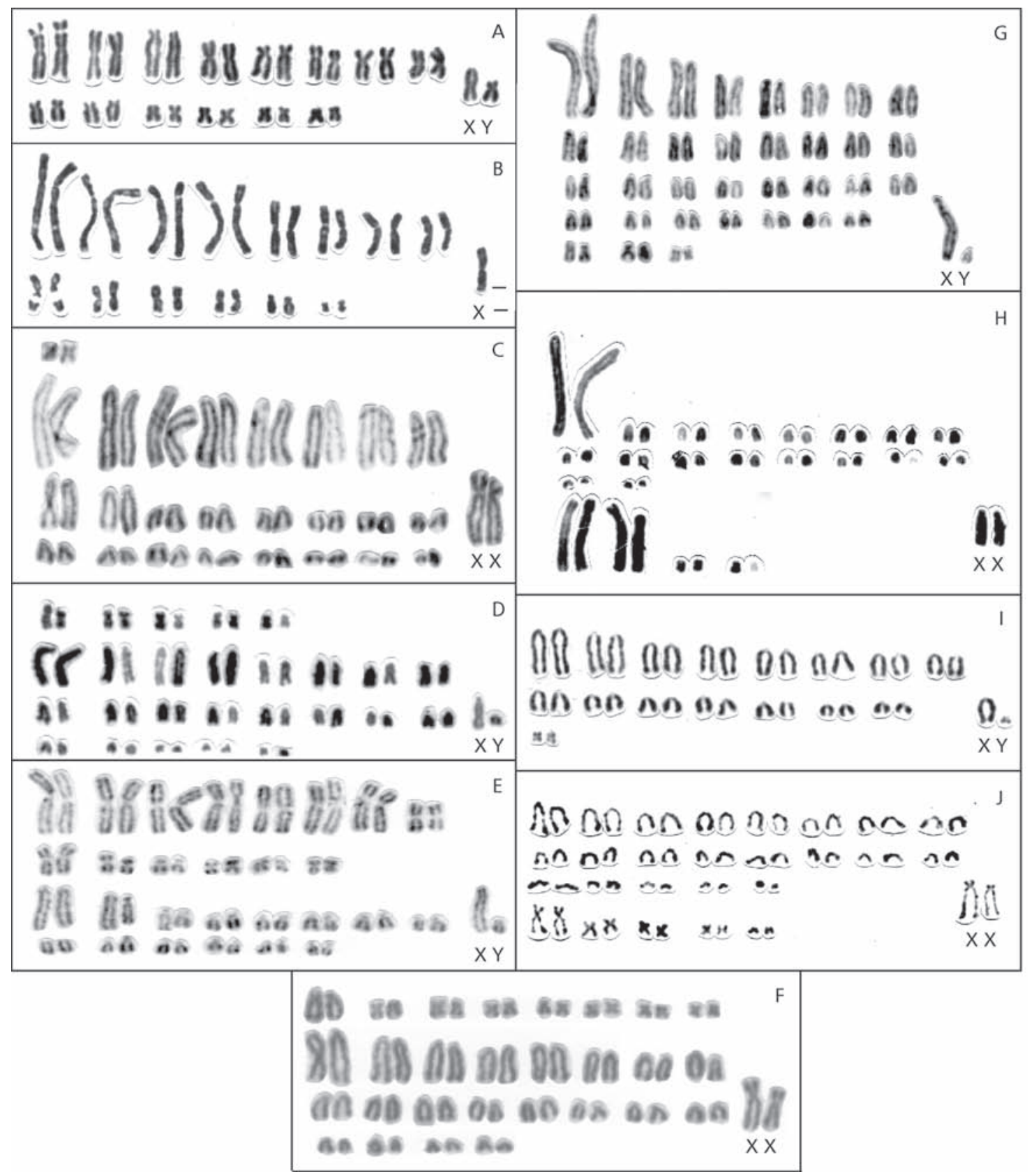

Fig. 2 - Conventional giemsa-stained karyotypes of: (A) Thrichomys sp. (male MN50177), (B) Proechimys roberti (male MN50213), (C) Nectomys rattus (female MN46873, (D) Oryzomys megacephalus (male MN43006), (E) Oryzomys lamia (male CRB983), (F) Oryzomys scotti (male MN61679), (G) Oligoryzomys moojeni (male MN50314), (H) Oligoryzomys rupestris (female MN50324), (I) Necromys lasiurus (male MN46824), (J) Oxymycterus delator (female MN46640). X = X chromosome, Y = Y chromosome. 
Distribution: Paraguay and C Brazil, in the cerrado and chaco (Oliveira, 1998).

Ecological notes and reproduction: 25 individuals collected, 22 in vereda and 3 in campo úmido (areas A2 and A3). Four pregnant females were collected in November (2-5 embryos each).

Measurements: $\mathrm{HB}=120-179, \mathrm{~T}=69-121$, $\mathrm{F}=22-31, \mathrm{E}=14-22, \mathrm{~W}=65-115$.

Specimens collected: MN46619-631, 46633641, 46648.

\section{Calomys expulsus (Lund, 1841)}

Taxonomy and karyotype: $C$. expulsus had been considered either a junior synonym (Musser \& Carleton, 1993) or a subspecies (Hershkovitz, 1962) of C. callosus. However, karyologic and morphological analysis showed that $C$. expulsus is a valid species (Bonvicino \& Almeida, 2000). Karyologic analyses showed $2 \mathrm{n}=66, \mathrm{FN}=68$. Another karyotype has been attributed to C. expulsus ( $2 \mathrm{n}=36, \mathrm{FN}=66$; Geise et al., 1996) but it belongs to an undescribed species.

Distribution: $\mathrm{C}$ and NE Brazil, in the cerrado (Federal District, Bahia, Minas Gerais, and Goiás) and caatinga (Pernambuco and Piauí).

Ecological notes and reproduction: seven individuals collected, three in cerrado sensu stricto, two in campo úmido, one in gallery forest, and one in cerrado rupestre (areas A1 and A2). Females were not pregnant (August and November).

Measurements: $\mathrm{HB}=102-122, \mathrm{~T}=72-88, \mathrm{~F}=$ $18-22, \mathrm{E}=14-19, \mathrm{~W}=25-35$.

Specimens collected: MN61583-589.

\section{DISCUSSION}

Our species list constitutes convincing evidence of the limited knowledge of the taxonomy of small mammals in the cerrado. Of the 19 collected species, 12 have recently been reviewed or described. This is the case of Oligoryzomys rupestris and Oligoryzomys moojeni (Weksler \& Bonvicino, 2005), Monodelphis umbristriata (Lemos et al., 2000), Thylamys velutinus (Palma, 1995), Proechimys roberti (Weksler et al., 2001), Nectomys rattus (Bonvicino et al., 1996), Pseudoryzomys simplex (Voss \& Myers, 1991), Oryzomys megacephalus (Musser et al., 1998), Oryzomys lamia (Bonvicino et al., 1998), Oryzomys scotti (Langguth \& Bonvicino, 2002), Oxymycterus delator (Oliveira, 1998), and Calomys expulsus (Bonvicino \& Almeida, 2000). One of the collected species is presently undescribed (Thrichomys sp.), one is probably composite (Micoureus demerarae), and one is as yet unclassified (Galea cf. flavidens). The lack of taxonomic resolution combined with the currently imprecise delimitation of their distribution patterns undermines the study of ecological or historical processes behind the existing structure of small mammal communities of the cerrado.

Although our collecting methodology was not intended to produce quantitative data for analyzing differences of the small mammal structure and composition associated with habitat heterogeneity, our qualitative results indicated a marked compositional difference between different phytophysiognomies that has been extensively documented in previous studies (e.g., Mello \& Moojen, 1979; Henriques \& Alho, 1981; Fonseca \& Redford, 1984; Alho et al., 1986; Mares et al., 1986, 1989; Bonvicino et al., 1996a). Seven species were predominantly found in gallery forest (Didelphis albiventris, Micoureus demerarae, Monodelphis umbristriata, Proechimys roberti, Nectomys rattus, Oryzomys megacephalus, and Oryzomys lamia), three in cerrado rupestre (Galea cf. flavidens, Thrichomys sp., and Oligoryzomys sp. 2) and three in vereda and campo úmido (Oxymycterus delator, Pseudoryzomys simplex, and Thylamys velutinus). Six species were extensively distributed throughout cerrado habitats but three of them were not found in gallery forest (Oryzomys scotti, Necromys lasiurus, and Gracilinanus agilis) while the other three occurred in this vegetation (Monodelphis domestica, Oligoryzomys sp.1, and Calomys expulsus). With the exception of very few cases each species was captured in the same habitat as recorded in previous studies except for very few cases, which is probably due to the small sample size of some taxa. Our data also showed the heterogeneity of cerrado small mammal fauna across elevations since only eight of the 19 species were collected at both high and low elevations. The extensive areas of forest formations at low elevations and of cerrado rupestre at high elevations are probably the main factor influencing the compositional heterogeneity of the small mammals from these two areas of Chapada dos Veadeiros National Park. 
Several authors have stressed the importance of gallery forest in boosting the diversity of the cerrado non-volant mammal fauna. This is because such areas are extensions or corridors of Amazonian and Atlantic forests into cerrado and, therefore, enable species adapted to these mesophytic habitats to inhabit open vegetation in the cerrado biome (Fonseca \& Redford, 1984; Redford \& Fonseca, 1986; Mares et al., 1986; Marinho-Filho, 1994). Our data is a further indication of the importance of gallery forest in housing a large parcel of cerrado diversity. Nevertheless, of the 19 species collected in the park, only 4, which are mesophyticadapted species (Nectomys rattus, Oryzomys megacephalus, Proechimys roberti and Micoureus demerarae), were distributed throughout the gallery forest of the cerrado and the Amazon forest. Other species occurring in the park have been listed as being present in the Atlantic or Amazon forests but, as mentioned previously, this was done without adequate taxonomic criteria. In addition, some scale factors account for erroneous conclusions. Thus, major biomes have been delimitated without considering either the mosaic transitional areas between them or, in the case of forested biomes, enclaves of cerrado vegetation types within them.

Our results indicated that the level of endemicity of the cerrado small mammalian fauna may be higher than previously estimated (Redford \& Fonseca, 1986). Six cerrado-endemic species were found in the park, representing one third of the collected species. Endemic species were present in almost all types of vegetation including gallery forest (Monodelphis umbristriata, Oryzomys lamia), cerrado rupestre (Oligoryzomys sp. 2), and various cerrado structural types (Oryzomys scotti, Oligoryzomys sp. 1, and Thrichomys sp.). Fonseca \& Redford (1984) reported 11 endemic, non-volant mammals, for the cerrado, including 10 small mammals. Three of the listed species (O. lamia, M. umbristriata, and Galea flavidens) occurred in the park while two others are in fact non-endemic to the cerrado (Pseudoryzomys simplex and Oligoryzomys utiaritensis, a synonym of Oligoryzomys nigripes) and six endemic species were not found in the park. These species are Echimys braziliensis, Ctenomys brasiliensis, Carterodon sulcidens, Juscelinomys candango, Thalpomys lasiotis (= Akodon reinhardti), and Lycalopex vetulus. Other small mammal species reported to be endemic in the cerrado include Oryzomys marinhus (Bonvicino, 2003), Juscelinomys huanchacae, and J. guaporensis (Emmons, 1999), Thalpomys cerradensis (Hershkovitz, 1990), and Oecomys cleberi (Locks, 1981). Consequently, the total number of endemic cerrado forms is 17 , of which 16 correspond to small mammals.

The data presented in the present work only allow hypotheses that involve historical and ecological factors to explain the present cerrado. To explain the small mammal diversity of the cerrado requires hypotheses based on more rigorous taxonomic studies of the cerrado taxa, further research on delimitation of their distribution in the vegetation mosaic of the cerrado, as well as comparisons with taxa found in extra-core cerrado locations. The importance of gallery forest in the formation of present cerrado mammalian fauna is well established. Probably equally important, as shown by species currently inhabiting only these environments, is the open vegetation belt composed of caatinga, cerrado, and chaco. Hypotheses relative to the specific process by which fauna in different areas of the cerrado, such as the high altitude sites that appear to contain similar endemic fauna not found at lower altitudes, are material for future research. Suggested sites for carrying out such investigations are the Planalto Central Goiano of the Brazilian Plateau (Pouso Alto in PNCV, in Serra Santana) and the Planalto do Espinhaço mountains of Eastern Brazil (Pico das Almas, Bahia, and Serra do Cipó, Minas Gerais, Fig. 2) where Oligoryzomys sp. 2 has also been collected (Silva \& Yonenaga-Yassuda, 1997).

Acknowledgements - We are grateful to L. F. de Oliveira (Museu Nacional, Rio de Janeiro) for access to MN collections, R. Cerqueira for laboratory facilities, and C. E. Grelle and three anonymous referees for helpful suggestions on an early draft of the manuscript. We thank S. M. Lindbergh, A. C. de Paula, L. S. Maroja, J. Freitas, and R. Finotti for help in fieldwork, as well as H. N. Seuánez for reviewing an earlier English version of this manuscript. The Instituto Brasileiro do Meio Ambiente e dos Recursos Naturais Renováveis (IBAMA) granted us a license for collecting specimens (license number: 052/96). This work was supported by CNPq/PRONEX, IBAMA. and IOCFIOCRUZ (Dep. Medicina Tropical). 


\section{REFERENCES}

ALHO, C. J. R., 1982, Brazilian rodents: their habitats and habits. Pymatuning Lab. Ecol. Spec. Publ., 6: 143-166.

ALHO, C. J. R., PEREIRA, L. A. \& PAULA, A. C. DE, 1986, Patterns of habitat utilization by small mammals populations in Cerrado Biome of Central Brazil. Mammalia, 50: 447460.

BONVICINO, C. R., 1994, Especiação do rato d'água Nectomys. Abordagem cariológica, morfológica $e$ geográfica. Unpublished D.Sc. Thesis, Universidade Federal do Rio de Janeiro, Brazil.

BONVICINO, C. R., CERQUEIRA, R. \& SOARES V. DE A., 1996a, Habitat use by small mammals of upper Araguaia river. Rev. Bras. Biol., 56: 761-767.

BONVICINO, C. R., D'ANDREIA, P., CERQUEIRA, R. \& SEUÁNEZ, H., 1996b, The chromosome of Nectomys (Rodentia, Cricetidae) with $2 \mathrm{n}=52,2 \mathrm{n}=56$ and interspecific hybrids $(2 \mathrm{n}=54)$. Cytogen. Cell Genet., 73: 190-193.

BONVICINO, C. R. \& WEKSLER, M., 1998, A new species of Oligoryzomys (Rodentia, Sigmodontinae) from Northeastern and Central Brazil. Z. Säugetierkunde, 63: 90-103.

BONVICINO, C. R., OTAZU, I. B. \& WEKSLER, M., 1998, Oryzomys lamia Thomas, 1901 (Rodentia, Sigmodontinae, karyotype, geographic distribution and conservation status. Mammalia, 62: 253-258.

BONVICINO, C. R., OTAZU, I. B. \& BORODIN, P. M., 1999, Chromosome variation in Oryzomys subflavus species group (Sigmodontinae, Rodentia) and its taxonomic implication. Cytologia, 64: 237-332.

BONVICINO, C. R. \& ALMEIDA, F. C., 2000, Karyotype, morphology and taxonomic status of Calomys expulsus (Rodentia: Sigmodontinae). Mammalia, 64(3): 339-351

BONVICINO, C. R., OTAZÚ, I. B. \& D'ANDREA, P. S., 2002, Karyologic evidences of diversification of the genus Thrichomys (Rodentia, Echimyidae). Cytogenet. Genome Res., 97: 200-204.

BONVICINO, C. R., 2003, A new species of Oryzomys (Rodentia, Sigmodontinae) of the subflavus group from the Cerrado of Central Brazil. Z. Säuetierkunde, 68(2): 78-90.

CABRERA, A., 1957, Catálogo de los mamíferos de América del Sur. Rev. Mus. Arg. Cienc. Nat. Bernadino Rivadavia, 4: 1-308.

CABRERA, A., 1961, Catálogo de los mamíferos de América del Sur. Rev. Mus. Arg. Cienc. Nat. Bernadino Rivadavia, 4: $1-750$.

CERQUEIRA, R., 1985, The distribution of Didelphis in South America (Polyprotodontia, Didelphidae). J. Biogeog., 12: 135-145.

EITEN, G., 1972, The cerrado vegetation of Brazil. Bot. Rev., 38: 201-341.

EITEN, G., 1983, Classificação da vegetação do Brasil. CNPq, Brasília.
ELLERMAN, J. R., 1940, The families and genera of living rodents. British Mus. (Nat. Hist.) London, 1: 1-689.

EMMONS, L. H., 1999, Two new species of Juscelinomys (Rodentia: Muridae) from Bolivia. American Museum Novitates, n. 3280, 15p.

FONSECA, G. A. B. \& REDFORD, K. H., 1984, The IBGE's ecological reserve, Brasília, DF and an analysis of the role of gallery forest in increasing diversity. Rev. Bras. Biol., 44: 517-523.

GARDNER, A. L., 1993, Orden Didelphimorphia, pp.15-23. In: D. E. Wilson \& D. M. Reder (eds.), Mammal species of the World. A taxonomic and geographic reference, $2^{\text {nd }}$ ed. Smithsonian Institution Press, Washington.

GARDNER, A. L. \& PATTON, J. L., 1976, Karyotypic variation in oryzomyine rodents (Cricetidae) with comments on chromosomal evolution in the neotropical cricetinae complex. Occas. Pap. Lousiana State Univ. Mus. Zool., 49: 1-48.

GARDNER, A. L. \& CREIGHTON, G. K., 1989, A new generic name for Tate's (1933) Microtarsus group of South American mouse opossums (Marsupialia: Didelphidae). Proc. Biol. Soc. Wash., 102: 3-7.

GEISE, L., HINGST, E., WEKSLER, M. \& CERQUEIRA, R., 1996, A new karyotype of Calomys (Rodentia: Sigmodontinae), with taxonomic considerations. Rev. Bras. Genet., 19: A45, supplement.

HENRIQUES, R. P. B. \& ALHO, C. J. R., 1981, Microhabitat selection by two rodent species in the cerrado of Central Brazil. Mammalia, 55: 49-55.

HERSHKOVITZ, P., 1962, Evolution of Neotropical Cricetine rodents (Muridae) with special reference to the phyllotine group. Field. Zool., 46: 1- 524.

HERSHKOVITZ, P., 1990, The Brazilian rodents genus Thalpomys (Sigmodontinae, Cricetidae) with description of a new species. J. Nat. Hist., 24: 763-783.

HERSHKOVITZ, P., 1992, The South American gracile mouse opossums, genus Gracilinanus Gardner \& Creighton, 1989 (Marmosidae, Marsupialia). A taxonomic review with notes on general morphology and relationships. Field. Zool. n.s., 70: 1-56.

HERSHKOVITZ, P., 1994, The description of a new species of South American hocicudo or long-nose mouse, genus Oxymycterus (Sigmodontinae, Muroidea), with a critical review of the generic content. Field. Zool n.s., 79: 1-43.

HERSHKOVITZ, P., 1998, Report on some sigmodontinae rodents collected in southeastern Brazil with descriptions of a new genus and six new species. Bonn. Zool. Beitr., 47: 193-256.

LANGGUTH, A., 1966, Application to place on the appropriate official list of names given by G. Fisher 1814 to the cricetid rodents described by Felix de Azara in the French translation of Essais sur l'historie naturelle des quadrupedes du Paraguay, 18091. Z.N. (S). 1774. Bull. Zoo.l Nomencl., 23: $285-288$.

LANGGUTH, A. \& BONVICINO, C. R., 2002, The Oryzomys subflavus species group, with description of two new species (Rodentia, Muridae, Sigmodontinae). Arq. Mus. Nac. Rio de Janeiro, 60(4): 285-294. 
LEMOS, B., WEKSLER, M. \& BONVICINO, C. R., 2000, On the taxonomic status of Monodelphis umbristriata (Didelphimorphia: Didelphidae). Mammalia, 64(3): 329-337.

LOCKS, M., 1981, Nova espécie de Oecomys de Brasília, DF, Brasil (Cricetidae, Rodentia). Boletim do Museu Nacional, 300: $1-7$.

MACÊDO, R. H. \& MARES, M. A., 1987, Geographic variation in the South American cricetine rodent Bolomys lasiurus. J. Mamm., 68: 578-594.

MAIA, V., YONENAGA-YASSUDA, Y., FREITAS, J. R. O., KASAHARA, S., SUNE-MATTEVI, M., OLIVEIRA, L. F. B., GALINDO, M. A. \& SBALQUEIRO, I. J., 1984, Supernumerary chromosomes in Nectomys squamipes (Cricetidae-Rodentia). Genetica, 63: 121-128.

MARES, M. A., ERNEST, K. A. \& GETTINGER, D. D., 1986, Small mammal community structure and composition in the cerrado province of Central Brazil. J. Tropical Ecol., 2: 289-300.

MARES, M. A., BRAUN, J. K. \& GETTINGER, D. D., 1989, Observations on the distribution and ecology of the mammals of the cerrado grasslands of Central Brazil. Annals of Carnegie Museum, 58(1): 1-60.

MARINHO-FILHO, J., REIS, M. L., OLIVEIRA, P. S. DE, VIEIRA, E. M. \& PAES, M. N., 1994, Diversity standards and mammal numbers: conservation of the Cerrado Biodiversity. An. Acad. Bras. Ci., 66, supl.1: 149-156.

MELLO, D. A. \& MOOJEN, L. E., 1979, Notas sobre uma coleção de roedores e marsupiais de algumas regiões do Cerrado do Brasil Central. Rev. Bras. Pesq. Med. Biol., 12: 287-291

MOOJEN, J., 1948, Speciation in the Brazilian spiny rats (genus Proechimys, family Echimyidae). Univ. Kansas Publ., 1: 301-406.

MOOJEN, J., LOCKS, M. \& LANGGUTH, A., 1997, A new species of Kerodon Cuvier, 1825 from Goiás, Brazil (Mammalia, Rodentia, Caviidae). Bol. Mus. Nacional n. s. Zool. Rio de Janeiro, 377: 1-10.

MUSSER, G. G. \& CARLETON, M. P., 1993, Family Muridae, pp. 501-755. In: D. E. Wilson \& D. M. Reeder (eds.) Mammal species of the World. A taxonomic and geographic reference, $2^{\text {nd }}$ ed. Smithsonian Institution Press, Washington.

MUSSER, G. G., CARLETON, M. D., BROTHERS, E. M. \& GARDNER, A. L., 1998, Systematic studies of oryzomyine rodents (Muridae, Sigmodontinae): diagnoses and distributions of species formerly assigned to "Oryzomys capito". Bul. Amer. Mus. Nat. Hist., 236: 1-376.

OLIVEIRA, J. A., 1998, Morphometric assessment of species groups in the South American rodent genus Oxymycterus. Ph.D. Dissertation, Texas Tech University, Lubbock, Texas, 320p.

PALMA, R. E., 1995, Range expansion of two South American mouse opossums (Thylamys, Didelphidae) and their biogeographic implications. Rev. Chil. Hist. Nat., 68: 515-522.

PATTERSON, B. D., 2000, Patterns and trends in the discovery of new Neotropical mammals. Diversity and Distributions, 6: 145-150.
PATTON, J. L., 1987, Species groups of spiny rats, genus Proechimys (Rodentia, Echimyidae). Field. Zool. n.s., 39: 305-345.

PATTON, J. L., SILVA, M. N. F. DA \& MALCON, J. R., 2000, Mammals of the rio Juruá and the evolutionary and ecological diversification of Amazonia. Bull. Amer. Mus. Nat. Hist., 244: 1-306.

PAULA-COUTO, C., 1950, Memórias sobre a paleontologia brasileira. Ministério da Educação e Saúde, Rio de Janeiro.

PESSOA, L. M., OLIVEIRA, J. A. DE \& REIS, S. F. DOS, 1990, Quantitative cranial character variation in selected populations of the guyannensis-group of Proechimys (Rodentia: Echimyidae) from Brazil. Zoo Anzeiger, 225: 396-400.

PINE, R. H., 1979, Taxonomic notes on "Monodelphis dimidiata itatiayae (Miranda-Ribeiro)", Monodelphis domestica (Wagner) and Monodelphis maraxina Thomas (Mammalia: Marsupialia: Didelphidae). Mammalia, 43: 495-499.

RADAM-BRASIL, 1983, Projeto RADAMBRASIL. Programa de integração nacional. Levantamento de recursos naturais - Brasil, v. 31. Ministério do Minas e Energia, Rio de Janeiro, 765p.

REDFORD, K. H. \& FONSECA, G. A. B. DA, 1986, The role of gallery forests in the zoogeography of the Cerrado's nonvolant mammalian fauna. Biotropica, 18: 126-135.

SILVA, M. J. \& YONENAGA-YASSUDA, Y., 1997, New karyotype of two related species of Oligoryzomys genus (Cricetidae, Rodentia) involving centric fusion with loss of NORs and distribution of telomeric (TTAGGG)n sequences. Hereditas, 127: 217-229.

SVARTMAN, M. \& ALMEIDA, E. J. C. DE, 1992, The karyotype of Oryzomys capito laticeps (Cricetidae, Rodentia) from Central Brazil. Braz. J. Genet., 15: 963-972.

SVARTMAN, M. \& ALMEIDA, E. J. C. DE, 1993, Robertsonian fusion and $\mathrm{X}$ chromosome polymorphism in Zygodontomys (= Necromys) lasiurus (Cricetidae, Rodentia) from central Brazil. Braz. J. Genet., 16: 225-235.

TATE, G. H. H., 1933, A systematic revision of the marsupial genus Marmosa. Bull. Amer. Mus. Nat. Hist., 66: 1-250.

VOSS, R. S. \& MYERS, P., 1991, Pseudoryzomys simplex (Rodentia: Muridae) and the significance of Lund's collections from the caves of Lagoa Santa, Brazil. Bull. Amer. Mus. Nat. Hist., 206: 414-432.

WEKSLER, M., BONVICINO, C. R., OTAZU, I. B. \& SILVA JR., J. S., 2001, The status of Proechimys roberti and $P$. oris (Rodentia, Echimyidae) from eastern Amazonia and Central Brazil. J. Mamm., 82(1): 109-122.

WEKSLER, M. \& BONVICINO, C. R., 2005, Taxonomy of pigmy rice rats (genus Oligoryzomys, Rodentia: Sigmodontinae) of the brazilian Cerrado, with the description of two new species. Arquivo do Museu Nacional, 63(1): 113-130.

WOODS, C. A., 1993, Suborder Hystricognathi, pp. 771-806. In: D. E. Wilson \& D. M. Reeder (eds.), Mammals species of the world. A taxonomic and geographic reference, $2^{\text {nd }}$ ed. Smithsonian Institution Press, Washington. 